\title{
Alexandre Javakhishvili - the Founder of Modern Geography in Georgia
}

\author{
Koba Kharadze \\ Head of Department of Landscape Sciences, Vakhushti Bagrationi Institute of Geography, Tbilisi, Georgia
}

\section{Email address:}

koba.kharadze@tsu.ge

\section{To cite this article:}

Koba Kharadze. Alexandre Javakhishvili - the Founder of Modern Geography in Georgia. Earth Sciences. Special Issue: Engineering Seismology: An Interface Between Earthquake Science and Practical Engineering. Vol. 4, No. 5-1, 2015, pp. 79-83.

doi: $10.11648 /$ j.earth.s.2015040501.24

\begin{abstract}
The article describes the contribution of Alexandre Javakhishvili to the geographic, cartographic and anthropologic development of Georgia. The scientific production created under his editorship and management is also described. The scientist contributed much to the study of history of the geographical development, where Vakhushti Bagrationi played a leading role. The article shows the scientist's merit in the geographical and cartographic development.His studies developed the methodological issues of the different branches of geographical science (principles of geomorphological zoning, definition of the subject of regional geomorphology, classification of the types of relief and their relations to the geology and tectonic structure, etc.), identified the physical-geographical peculiarities of the territory of Georgia (thermal zones, types of precipitations, etc.) and developed zoning plans (geomorphological, climatic, hydrological, etc.), developed a series of thematic maps of Georgia in different scales (general geographic, geomorphological, climatic, etc.) and analyzed the anthropogenic types of different corners of Georgia and identified the Georgians as an individual anthropogenic type.
\end{abstract}

Keywords: Alexandre Javakhishvili, Geography, Cartography, Anthropology

\section{Introduction}

Alexandre Javakhishvili was a Georgian geographer and anthropologist, the founder of Modern geography in Georgia. His qualifications and awards include: professor (1920), Doctor of Geographical Sciences (1937), an Academician of the Georgian Academy of Sciences (1944), a Merited Scientist, an honorary member of the Geographical Society USSR, and winner of a State Prize of the Georgia (1971). At Tbilisi State University he was the dean of the Faculty of Natural Sciences (1921-1922) and Faculty of Geography and Geography (1930-32, 1939-1940), Head of chair of General Geography and Anthropology (1920-1934) and chair of Geomorphology (1935-1973).

He actively participated in the foundation of Tbilisi State University and formation and organization of the Faculty of Natural Sciences, as shown by the Protocol of 17 October 1917. He contributed to the introduction and development of the geographical science in Georgia, as well as establishment of geographical institutions (departments, chairs, faculties, and museum) and growing up of young staff. During the entire period (1920-73) of his working at the University he organized several departments of geographical division, scientific-research and educational study rooms, Geographical Museum and library. By his initiative and leadership the Georgian Geographical Society (1924) and Vakhushti Bagrationi Institute of Geography (1933) have been founded. He also founded the departments, chairs, faculties at Teacher training colleges at Batumi, Gori, Kutaisi [1,2].

Al. Javakhishvili founded the Geographical Society of Georgia (1924) and became the Vice President (1924-1940), President (1940 -1970) and Honorary President (1970-1973) of this society. In 1933 he founded the Institute of Geography and managed the institute during 1933-1962 [3,4].

His research solved the cardinal problems of geography of Georgia and anthropology of the population of the Caucasus. He made approximately 300 scientific works, covering almost all the geographical problems of Georgia: geomorphology, cartography, landscape science, the territorial distribution of the population, the history of geography of Georgia (Fig. 1).

Al. Javakhishvili made a significant contribution to the methodology of geographical science. His works are devoted to the issues of the structure of Geography as a science, to the interrelations between Geography and other branches of the 
sciences.

For merits in scientific and public activities Al. Javakhishvili was awarded the Orders and Medals. His name was granted one peak of Great Caucasus in Racha, Georgia (Fig. 2).

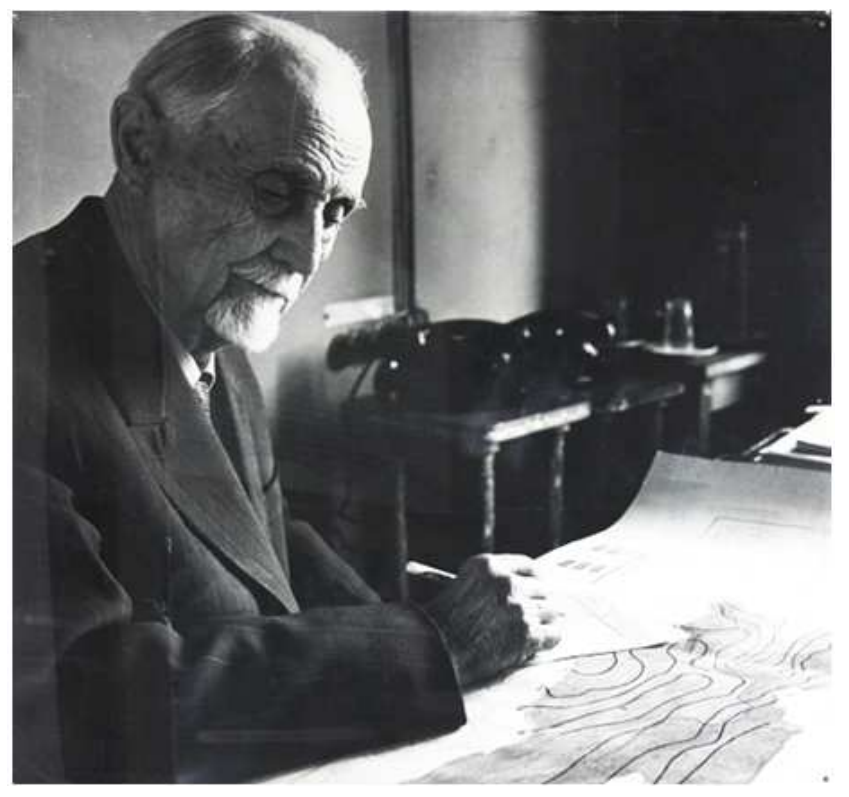

Fig. 1. Alexandre Javakhishvili

\section{Main Results}

\subsection{Researches in Different Branches of Geography}

Al. Javakhishvili published about 400 works, including the text-books for higher educational institutions and secondary schools, monographs and scientific articles [5]. Aiming at thoroughly assessing his scientific heredity, his scientific works were analyzed, including those in different branches of geography, cartography and anthropology. The study also used the reviews by Al. Javakhishvili regarding various anthropogenic works by foreign scientists, as well as archives and fund materials.

Al. Javakhishvili assigned a certain place to the geomorphological issues of Georgia in his works. At the first stage, it was necessary to develop the general geomorphologic description what he did as early as in 1926 and published as "Geography of Georgia" with a geographical atlas [6]. He published his works in geomorphologywith the map and legend of the map of Georgia, scaled 1:200,000 [7,8]. These works give the rich geomorphological materials being actual even to date.

These works give not only geomorphological analysis of Georgia, but also the issues of general geomorphology, such as subject and objectives of geomorphology, principles of geomorphological zoning, definition of the subject of regional geomorphology, classification of the types of relief and their relations to the geology and tectonic structure.

Al. Javakhishvili studied the exogenous, morphographic, morphogenetical and morphological types of the relief in
Georgia.

The works by Al. Javakhishvili in the fields of climatology and hydrology are very important. Based on the many-year meteorological observation data, he identified the thermal zones and types of precipitations in Georgia. For example, he identified 5 temperature types on the plains of Kartli and Kakheti and matched them with the following hypsometric elevations: 200-300, 300-500, 500-600, 600-750 da 750-900 $\mathrm{m}$ above sea level [9].

In order to receive a picture of the geographical distribution of the thermal regime, he plotted the lakes on the map scaled $1: 400,000$, and thus received the map of the thermal zones of Georgia. The analysis of this map shows the dependence of the thermal regime on the peculiarities of the horizontal and vertical development.

In addition, Al. Javakhishvili associates the distribution of thermal zones on the territory of Georgia with the complexity of the relief and peculiarities of the horizontal and vertical distribution.

In relation to the types of the relief and climatic peculiarities, Al. Javakhishvili also gives the hydrological zoning of Georgia by considering the gradient and relief forms of the surface [9].

The works by Al. Javakhishvili about the issues of physical-geographical and economic-geographical zoning are very important. He developed the guiding principles and tasks to be the basis for zoning. He identifies 3 principal physical-geographical regions on the territory of Georgia: Great Caucasus ("Caucasioni"), plain and south mountainous area. Within the scope of the Great Caucasus, he identifies eastern and western regions, and vertical zones among them. Al. Javakhishvili divides the plain into 5 units (Colchis Plain, Imereti Plateau, Kartli Plain, Kakheti Plain, Shiraki Plateau), and divides the South Georgian mountainous area into 4 units (Ajara-Guria, Samtskhe, Trialeti and Javakheti mountainous areas) [10].

For the geomorphological, climatic, hydrological and landscape issues of Georgia, Al. Javakhishvili developed thematic maps. These maps are important for developing individual branch and geographical disciplines. In addition, they played an important role in the development of map-making methods in Georgia.

Some works of Al. Javakhishvili were devoted to the issues of Military geography [10]. In order of this he wrote Geographical Essays of Iran and Turkey (1942), Geographical Features of Black Sea Coastal lien along the Batumi-Sinope (1943), Geographical Science for the State Defense (1944), Physical-geographical Essay of Caucasus (1945) [2].

\subsection{Al. Javakhishvili as a Cartographer}

Academician Al. Javakhishvili contributed much to the development of rich cartographic production. As early as during his work in Moscow, he included many of his cartographic images in his works and further, expanded his work whilst in Georgia. He paid a particular attention to drafting and publishing school teaching maps. Orographic, 
hypsometrical, mineral wealth, political and administrative maps of Caucasus scaled 1:800,000 (48 X $64 \mathrm{~cm})$ of 1925 drafted in relief color Indian ink are worth mentioning among them. The maps were drafted on every 20th net from longitudinal Greenwich.

These maps served a good purpose for the schools of that time and the publication of these maps was the first step in the development of cartographic activities in Georgia. In 1926, a geographical atlas of Al. Javakhishvili including 15 maps was published [3]. Most of the maps were drafted for the first time. In 1928, the scientist developed the atlas of practical exercises for the first time in the geography of Georgia. He continued this work further and drafted an atlas with 24 maps. Together with Sergi Tskhakaia, a teaching physical map scaled 1:400,000 was drafted and published. A hypsometric map of Georgia of 4 pages of the same scale was also drafted.

In 1931-1932, under the leadership of Al. Javakhishvili, a map of Georgia of a larger scale $(1: 200,000)$ of 12 pages was drafted and published with the relief with an Indian ink and isohypses. It was the first capital map widely recognized. By that time, it was the only map in the Georgian language with its polygraphic quality not a bit inferior to the West European standards.

Besides, Al. Javakhishvili compiled and edited quite a large number of thematic maps [12] in a different branches of geography. The functions of these maps are different: scientific, educational, reference appointment, etc.

\subsection{Researches in Historical Geography}

Al. Javakhishvili published relevant works on the issues of history of geography, geographical studies and achievements of Georgia. Worthwhile is the development of geography in the Soviet period, geographical heredity of Vakhushti Bagrationi, etc. This was particularly important, as demonstrating the past geographical heritage of the Georgian people and its importance to develop the issues of geographical study and cartographic science of Georgia. In relation to the anthropogenic description of Georgian and Caucasian population, Al. Javakhishvili widely used the historical and geographical works by Vakhushti Bagrationi.

This is how Al. Javakhishvili evaluates the composition by Vakhushti Bagrationi: "Old Georgia did not have another book describing our country as thoroughly as this one. This is why this work, as the first attempt to thoroughly describe Georgia, is a greatest historical treasure. It is similarly valuable as one of the oldest and most thorough monument of Georgian geographical science" [13].

Under near the end of the World War Two, Al. Javakhishvili was charged by the government with presenting a work about historical south-west of Georgia what the scientist accomplished successfully based on the works by Vakhushti Bagrationi. Recently, this work was found in the archives by historians [14]. In January of 1945, the Central Committee of the Communist (Bolshevik) Party of Georgia received an essay by Al. Javakhishvili "South-western Georgia as described by Vakhushti Bagrationi". The work by Al.
Javakhishvili was dated by January 7, 1946. It is clear that the author had been charged with writing the essay some time before.

\subsection{Al. Javakhishvili as a Anthropologist}

A. Javakhishvili conducted his anthropological investigations in different regions of Georgia: Kartli (1903-1904, in Kakheti and Mtiuleti (1905), in Imereti and Racha (1908), in Guria (1909) and in Samegrelo (1911). He made a lot of craniological studies in the Chair of Anthropology and Geography at Tbilisi State University, Georgia (Fig. 3). He submitted the main results in articles ("Society of Lovers of Natural Science, Anthropology and Ethnography") and monographs ("Anthropology of Georgia", vol. 1-2) [15]. These works received the highest award of the Society of Natural Sciences, Anthropology and Ethnography.

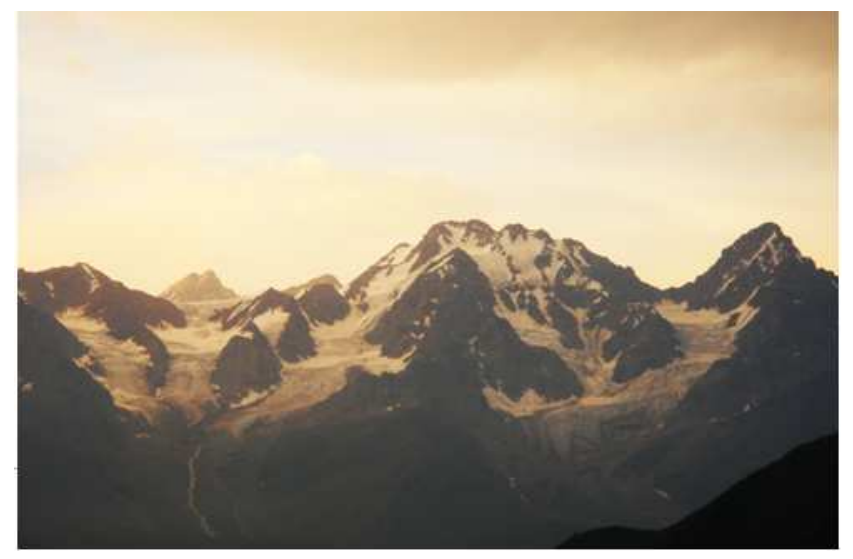

Fig. 2. Peak Alexandre Javakhishvili

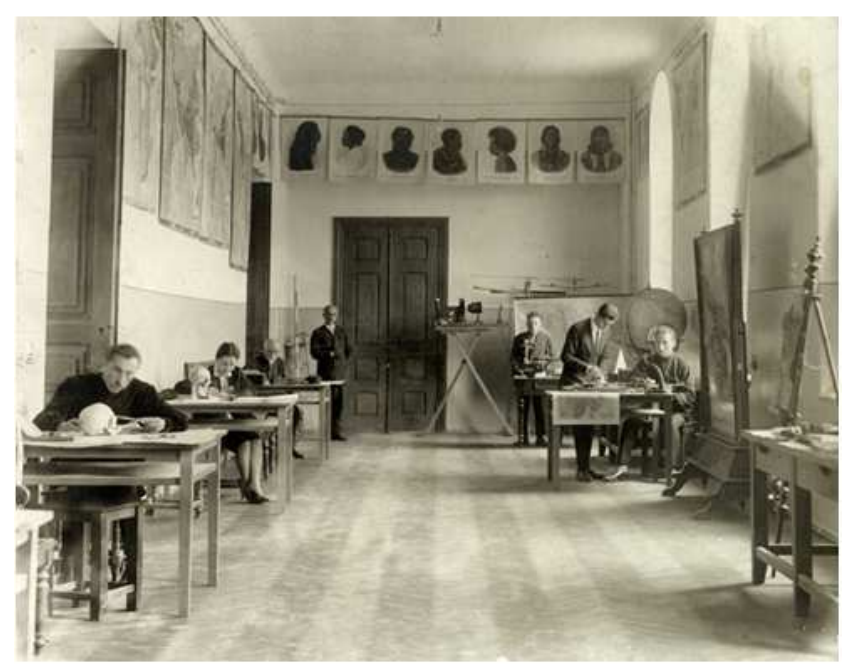

Fig. 3. Craniological Observations in the Chair of Anthropology and Geography at Tbilisi State University, Georgia, Edge of 1920-1930s

In these works he supplied geographical, ethnographical, historical and anthropological data. This was novelty in that time. All of his works made a great contribution to the study of anthropology of Caucasus. He studied the Jews, other nations of Caucasus [16].

A. Javakhishvili came to the conclusion that the Georgians 
according to their anthropological features, represent a united race with just a few minor differences between them and that the Georgians belong to the autochthonous population of the Caucasus [17]. During the same period A. Javakhishvili worked on such an important problem of anthropology as dolichocephaly among Georgians [3]. This view is completely new for that period and agree with the opinions of the linguists.

A. Javakhishvili reviewed a number of scientific publications written by foreign anthropologists such are: Adolf Dirr, Hans Wirhoff, T. Kluge, Muskat, Felix von Luschan, Hans Felinger, Otto Eichel, Otto Schlaginhauffen, et al. [18-25].

\section{Conclusions}

Some works by Al. Javakhishvili had a major influence on the development of geography and anthropology in Georgia. Despite the long time since his publications, they have not lost their scientific importance.

Through his studies, Al. Javakhishvili:

- Developed the methodological issues of the different branches of geographical science (principles of geomorphological zoning, definition of the subject of regional geomorphology, classification of the types of relief and their relations to the geology and tectonic structure, etc.);

- Identified the physical-geographical peculiarities of the territory of Georgia (thermal zones, types of precipitations, etc.) and developed zoning plans (geomorphological, climatic, hydrological, etc.);

- Developed a series of thematic maps of Georgia in different scales (general geographic, geomorphological, climatic, etc.).

- Analyzed the anthropogenic types of different corners of Georgia and identified the Georgians as an individual anthropogenic type.

\section{Acknowledgements}

We thank the colleagues from the National Archives form Georgia, Museum of Tbilisi State University and Alexandre Javakhishvili Geographical Society of Georgia, who provided this research by fund materials that greatly assisted the work.

\section{References}

[1] K. Kharadze. "The Great Merit of the Distiguished Patriot Academian Aleksadre Javakhishvili. Tbilisi, Tbilisi State University, 2015. 412 p. In Georgian.

[2] Sh. Kipiani. "Life and scientific-educational Activities". Essays of Geographic Science and Education. Tbilisi, Georgian Academy of Sciences Publishing House, 1957. 171 pp. In Georgian.

[3] Sh. Kipiani. Alexandre Javakhishvili. Tbilisi, Nakaduli, 1971, 79 p. In Georgian.
[4] Georgian Travelers, Geographers, Explorers of Nature. The Encyclopedic Reference Book. Tbilisi, Ganatleba Publishers, 2003. 335 p. In Georgian.

[5] K. Kharadze. Academician Al. Javakhishvili. Materalias third Republic-wide Education Methodological and Scientific Conference of Geographers, dedicated to 160th anniversary of Academician of Alexandre Javakhishvili, 16 May, 2005. pp. 5-7. In Georgian.

[6] Al. Javakhishvili. "Geography of Georgia", v. I, Geomorphology. Tbilisi: Tbilisi State University, 1926. 305 p. In Georgian. In Georgian.

[7] Al. Javakhishvili. Types and forms of relief. Academy of Science of USSR. Moscow-Leningrad, 1947. In Russsian.

[8] Al. Javakhishvili. Geomorphological Regions of Georgia. Publishing papers of Institute of Geography. Tbilisi, 1980. In Georgian.

[9] Al. Javakhishvili. "Hydrographic Division of Georgia, with Map of hydrographic division of Georgia". scale 1: 400,000. Tbilisi, Tbilisi State University, The scientific session. 1940. 7.11 May. pp. 45-46.

[10] Al. Javakhishvili. "Geographic Science in the State security service". Scientific Session, May 3-6. Tbilisi, 1944, pp. 5.

[11] Al. Javakhishvili. Al. "Javakhishvili.Dolichocephalism among the Georgians", the Russian Anthropogenic Journal, 1913, vol. 35-36, \#3-4, pp. 93-100.

[12] Atlas of Georgia. Moscow-Tbilisi, 1964. In Georgian and Russian.

[13] Vakhusti Bagrationi. "Description of the Kingdom of Georgia". The Georgian Chronicles, vol. 4. ed. S. Kaukhchishvili. Tbilisi, 1973. In Georgian.

[14] V. Guruli, L. Jikia. "Researches in Tao-Klardjeti"."The Matsne", \# 2, 2012, pp. 118-125. In Georgian.

[15] Al. Javakhishvili. Anthropology of Georgia. vol. 1-2. Moscow, 1908-1914.

[16] Al. Jvakhishvili. "The Caucasian Jewish (regarding the article by S. Weisenberg)", the Russian Anthropogenic Journal, 1912, vol. 32 , \#4, pp. 57-75.

[17] Al. Javakhishvili. Vertical Distribution of Settlements and Population Dispersion in Georgian Caucasioni. Alexander Javakhishvili works, vol. I. Papers on Anthropology. Tbilisi, 1990. pp. 252-286. In Georgian.

[18] Al. Javakhishvili. Dirr. Adolf. Anthropologische und ethnographische ûbersicht ûber die Völker des Kaukasus. "Mittelilungen (Petermanns) aus Justas "Parthesgeorgischer Anstalt", 1912, Heft: Jannar, s. 17-19 and Marz, s. 135-139. Дирр А. М. Антропологический и этнографический состав Кавказских народов. Кавказский календарь, 1910, ч. I, отд. III, c. 538-549 [Рец.]. Русский антропологический журнал, 1912, кн. 30-31, № 2-3, с. 175-179.

[19] Al. Javakhishvili. Kluge Th. Aufgaben und Ziele der vergleicher Kaukasischen Sprachwissenschaften. Zeitschrift fur Ethnologie, 1912, Heft I. [Рец.]. Russian Anthropological Journal, 1912, кн. 32, № 4, c. 96-97.

[20] Al. Javakhishvili. Virchow Hans. Stellung der Haare im Braunkopfe. Zeitschrift fur Ethnologie, 1912, Heft II. [Рец.]. Russian Anthropological Journal, 1912, кн. 32, №4, c. 97-98. 
[21] Al. Javakhishvili. Aichel Otto. Uber Entwicklung des Jnka-Reines. Zeitschrift fur Ethnologie, 1913, Heft III, s. 627-628. [Рец.]. Russian Anthropological Journal, 1913, кн. 35-36, № 3-4, c. 122-123.

[22] Al. Javakhishvili. Fehlinger Hans. Verianderungen der Korperformen bei Nachkommen der Eeinwanderer in den Vereinigtenstaaten. _Petermanns Mitteilungen, 1913, Juli-Helt. [Рец.]. Russian Anthropological Journal, 1913, кн. 33-34, № 1-2, c. 197-199.

[23] Al. Javakhishvili. Luschan v. Felix. Beitruge zur Anthropologie von Kreta. _ Zeitschrift fur Ethnologie, 1913, Helt III, s.
307-393. [Рец Russian Anthropological Journal, 1913, кн. 35-36, № 3-4, c. 118-122.

[24] Al. Javakhishvili. Muskat Dr. Ein einfaches verfahren zur Aufnahme von Tussabdrucken. Korresp. Blatt d. deutsh. Gessell. fur Anthr., Ethnol., u Urgesch, 1913, № 2-3. [Рец.]. Русский антропологический журнал, 1913, кн. 33-34, № 1-2, c. 202.

[25] Al. Javakhishvili. Schlaginhaufen Otto. Zur Technik Hand und Fussab-druche. "Korresp. _ Blatt der Deutschen Gessellschaft fur Anthr., Ethnol. u Urgesch.", 1913, № 2/3. [Рец.]. Russian Anthropological Journal,1913, кн. 33-34, № 1-2, с. 201-202. 